PHILIPP THER

Uniwersytet Wiedeński

\title{
CZECHOSŁOWACJA JAKO PAŃSTWO POHABSBURSKIE. ROZWAŻANIA O CIĄGŁOŚCI DZIEJÓW PRZED I PO 1918 ROKU
}

W tym roku, z powodu środkowoeuropejskiego nawyku obchodzenia jubileuszy historycznych, ciągle mamy do czynienia $\mathrm{z}$ retrospekcjami ${ }^{1}$. Rok 1918 z jednej strony był momentem rozpadu i dezintegracji, z drugiej nowego początku i integracji państwowej. Najnowsze publikacje o późnej monarchii habsburskiej można streścić tak: nie była ona predestynowana do rozpadu. Żołnierze cesarsko-królewskiej armii, wśród nich setki tysięcy Czechów, Polaków i Ukraińców, mimo wyczerpania i narzekań trzymali się niezawodnie na frontach I wojny światowej niemal aż do zawieszenia broni jesienią $1918 \mathrm{r}$. Ich postawa stała w sprzeczności z wszystkimi fałszywymi pogłoskami o zdrajcach czeskich lub słowiańskich, które były puszczane $\mathrm{w}$ świat przez wysokich rangą dowódców wojskowych i nacjonalistów niemieckich; przez wojskowych przede wszystkim po to, by odwrócić uwagę od tego, że oni sami zawiedli. Podejrzenia, których skutkiem były liczne niesprawiedliwe procesy przed sądami wojskowymi i wyroki śmierci, należą już do prehistorii rozpadu.

Historia Austro-Węgier mogła się przecież skończyć inaczej, natomiast od dawna pisana jest właśnie z perspektywy jesieni roku 1918 i rozpadu monarchii. W żadnym wypadku nie jest też jasne, jak by się na pierwszy rzut oka mogło wydawać, czy imperium, abstrahując od państwowości, rzeczywiście w 1918 r. uległo całkowitej likwidacji. Żyło nadal

${ }^{1}$ Czeska wersja tego artykułu ukaże się w czasopiśmie „Střed”, wydawanym przez Instytut im. Masaryka Czeskiej Akademii Nauk. Tezę o zdradzie obala Richard Lein, Pflichterfüllung oder Hochverrat? Die tschechischen Soldaten Österreich-Ungarns im Ersten Weltkrieg, Wien 2011. 
w literaturze, muzyce, architekturze i wielu obszarach kultury codzienności. Owo dziedzictwo imperialne, nawet jeśli było bardzo sporne i w wielu państwach sukcesyjnych zostało z powodów politycznych odrzucone, naznaczyło w szczególny sposób Czechosłowację. W tym eseju stawiam tezę, że to właśnie Czechosłowacja - a nie Republika Austrii, która dziś w turystyce i niekiedy polityce zagranicznej występuje chętnie w postaci postimperialnej - była tym państwem sukcesyjnym, które pod względem struktur i potencjału rozwojowego najbardziej upodabniało się do Austro-Węgier.

Do przyczyn rozpadu zalicza się od dawna konflikty narodowościowe. Jan Křen szczególnie wnikliwie zanalizował wewnętrzne rozdarcie i konflikty niemiecko-czeskie ${ }^{2}$. Jednakże, mimo niezrealizowanego trializmu (tj. nierozszerzenia kompromisu austriacko-węgierskiego o trzeci naród) i różnych niemiecko-czeskich blokad, od wydania konstytucji grudniowej 1867 r. Austro-Węgry rozwijały się jako państwo prawa, które na dodatek wstąpiło na drogę demokratyzacji ${ }^{3}$. Przed ponad trzydziestu laty pokazał to już Gerald Stourzh, jeden z najważniejszych historyków austriackich ery powojennej, w książce o równouprawnieniu narodowości $^{4}$. Amerykański historyk Pieter Judson w swej wielkiej syntezie podkreślił znowu ich zdolność do modernizacji 5 . Gospodarczo Austro-Węgry również dobrze prosperowały i nadganiały Europę Zachodnią. Dawnego przeciwstawienia między skazanymi na upadek, zacofanymi imperiami i nowoczesnymi państwami narodowymi, upowszechnianego zdumiewająco zgodnie przez historyków zarówno liberalnych, jak i marksistowskich, nie daje się już podtrzymywać w świetle aktualnego stanu badań, w każdym razie jeśli wziąć pod uwagę Austro-Węgry.

Potencjał demokratyzacji staje się wyraźniejszy, jeśli się przyjrzeć monarchii habsburskiej w porównaniu z innymi imperiami, choćby Cesarstwem Niemieckim, które wielu wielkoniemieckim nacjonalistom w Austrii

2 Por. J. Křen, Die Konfliktgemeinschaft. Tschechen und Deutsche 1780-1918, München 1996 (powołuję się tu na niemieckie wydanie uzupełnione, nie czeski oryginał). Warta wspomnienia jest też dobra monografia Piotra Majewskiego, Niemcy sudeccy 1848-1948. Historia pewnego nacjonalizmu, Warszawa 2007.

${ }^{3}$ Do zmarnowanych szans zalicza się także motywowana kłopotami budżetowymi, skierowana do cesarza oferta z 1891/1892 r. związanej z partią staroczeską dyrekcji Czeskiego Teatru Narodowego, by władca uznał ów prestiżowy dla czeskiego ruchu narodowego obiekt za teatr dworski, por. P. Ther, Národni divadlo v kontextu evropských operních dějin (od založeni do první světové války), Praha 2008, s. 200.

${ }^{4}$ G. Stourzh, Die Gleichberechtigung der Nationalitäten in der Verfassung und Verwaltung Österreichs 1848-1918, Wien 1985, s. 213-229.

${ }^{5}$ P.M. Judson, The Habsburg Empire. A New History, Cambridge 2016 (wydanie pol.: Imperium Habsburgów. Wspólnota narodów, Warszawa 2017). 
służyło za przykład. Demokratyzacja Prus była zablokowana z powodu ich „negatywnej polityki wobec Polaków” (Klaus Zernack), ucisk Polaków bez miary i celu osłabił także państwo prawa ${ }^{6}$. Austria natomiast w 1907 r. wprowadziła powszechne prawo wyborcze do Rady Państwa. Na poziomie regionów, przykładowo przy ugodzie morawskiej (1905), również zaznaczała się tendencja do demokratyzacji. To odcisnęło piętno na myśleniu i oczekiwaniach elit politycznych, w tym posła do Rady Państwa, Tomáša Garrigue Masaryka. Jego idealizacja demokracji nie brała się szczególnie z jej zdobyczy, a raczej z jej deficytów w okresie późnej monarchii.

Nie powinno się mimo wszystko przeceniać procesu demokratyzacji monarchii dualnej, ponieważ obejmowała ona jedynie austriacką połowę państwa. Poza tym reforma prawa wyborczego 1907 r. wykluczała kobiety. Na poziomie gmin, który jest dla demokracji równie ważny jak ogólnopaństwowy, nadal rządziło klasowe prawo wyborcze, tak że nie było tam równej reprezentacji i partycypacji. Kompromisy zawarte przy okazji konfliktów narodowościowych również powinny być poddane krytycznemu oglądowi. Ugoda morawska wzmocniła podziały społeczeństwa według kryteriów narodowościowych i uczyniła z nich podstawę procesu demokratycznego tworzenia woli politycznej. Jak to wszystko nie funkcjonowało, można pośrednio oglądać w Libanie i po 1995 r. w Bośni i Hercegowinie, gdzie demokracja opiera się na porównywalnych etnicznych i narodowych podziałach i filarach. Społeczeństwo Austro-Węgier było poza tym klasowe ze wszystkimi tego wadami.

Wszelako mocarstwo to było zdolnym do rozwoju tworem państwowym, który rozpadł się przede wszystkim dlatego, że swe wewnętrzne napięcia w roku 1914 przemienił w agresywną politykę zagraniczną i w trakcie Wielkiej Wojny przekształcił się z częściowo już zdemokratyzowanego państwa prawa w brutalną dyktaturę wojskową ${ }^{7}$. Mogłem to sam obserwować dzięki pamięci mojego dziadka z okresu I wojny światowej, gdy przed paru laty odnalazło się uznane za zaginione archiwum rodzinne ${ }^{8}$. Dziadek służył jako oficer w Pradze i donosił bez skrępowania o tym, jak źle i poniżająco traktowani byli czescy rekruci. Mówienie o „więzieniu narodów” jest usprawiedliwione akurat dla lat 1914-1918, gdy sądownictwo wojskowe wydało setki niesprawiedliwych wyroków

${ }^{6}$ O tym por.: P. Ther, Deutsche Geschichte als imperiale Geschichte. Polen, slawophone Minderheiten und das Kaiserreich als kontinentales Empire, w: Das Kaiserreich transnational. Deutschland in der Welt 1871-1914, red. S. Conrad, J. Osterhammel, Göttingen 2004, s. 129-148.

7 Por. P. Judson, op. cit., s. 391-399. Perspektywa porównawcza: W. Borodziej, M. Górny, Nasza wojna, t. 1: Imperia 1912-1916, Warszawa 2014, s. 107-133.

8 Por. Krkonošské muzeum Správy KRNAP, Vrchlabí, archiv, fond A008 Therové, složka A8/4, karton 17. 
śmierci. Tę pogardę dla człowieka, przemoc i samowolę uchwycił Jaroslav Hašek w swej powieści o dobrym żołnierzu Szwejku. Za granicą książkę często mylnie odbierano jako dzieło lekkie, lecz przecież było ono bliskie doświadczanej rzeczywistości. Głód na froncie wewnętrznym był osobnym problemem i wzmocnił jeszcze dodatkowo konflikty między narodowościami i klasami społecznymi ${ }^{9}$.

Dezintegracja Austro-Węgier w 1918 r. nie była spowodowana jedynie przez wewnętrzne napięcia i konflikty, lecz wspierana przez aktorów zewnętrznych. Licząca 14 punktów Deklaracja prezydenta USA Thomasa Woodrowa Wilsona była wotum nieufności wobec państwa habsburskiego i wytworzyła próżnię władzy w środku Europy. Cesarz Karol I był zbyt niedoświadczony i reagował zawsze o jeden krok za późno, by móc zapobiec rozpadowi.

Czy kres monarchii oznaczał rzeczywiście zmierzch, rozpad całego świata, co sugerują nam przede wszystkim niemieckojęzyczni pisarze jak Stefan Zweig, Robert Musil i pochodzący z Galicji Joseph Roth? Śmiem przywołać tu już wspomnianą tezę, że właściwym państwem sukcesyjnym starej Austrii nie była Republika Austrii, lecz Czechosłowacja. Teza ta stoi oczywiście w sprzeczności z jej rozumieniem samej siebie jako państwa. Założyciele republiki zdecydowanie przeciwstawiali się poprzedniczce, która była zniesławiana jako więzienie narodów, przyczyna ciemnoty (temno) i jako państwo feudalne. Owa antyaustriacka retoryka była przypuszczalnie konieczna, by uporać się z traumą I wojny światowej i by uzasadnić początek republiki demokratycznej. Podobnie jak Polska, Czechosłowacja czuła się „państwem zwycięskim”, zgoła w przeciwieństwie do oczywistych przegranych Wielkiej Wojny - Austrii i Węgier. Taki obraz własny niósł z sobą różnorakie korzyści: państwo czechosłowackie nader sprawnie opanowało wszechobecną po wojnie przemoc, przynajmniej w porównaniu do innych państw sukcesyjnych Austro-Węgier. Państwowy monopol na przemoc został wprowadzony dość szybko i całkowicie, uniknięto także hiperinflacji, w przeciwieństwie do wielu krajów sąsiednich ${ }^{10}$.

Ta rewizjonistyczna teza o pozytywnej kontynuacji między Austro-Węgrami i Republiką Czechosłowacką stoi w pełnym napięcia stosunku

9 R. Kučera, Život na prríděl. Válečná každodennost a politiky dělnické tř́dy v českých zemích 1914-1918, Praha 2013.

10 O przemocy po wojnie por. m.in.: R. Kučera, Exploiting Victory, Bewailing Defeat. Uniformed Violence in the Creation of the New Order in Czechoslovakia and Austria 1918-1922, "Journal of Modern History" 88, 2016, s. 827-855. O zanikaniu przemocy por. też. V. Šmidrkal, Fyzické násilí, státní autorita a trestní právo v českých zemích 1918-1923, „Český časopis historický" 114, 2016, 1, s. 89-115. 
do polityki historycznej Austrii. Przede wszystkim stolica - Wiedeń - od czasów powojennych prezentuje się jako metropolia (post)imperialna. Dzięki filmom o cesarzowej Sissi, które miały odwieść uwagę od narodowosocjalistycznej przeszłości, w zainscenizowanej nostalgii za czasami Habsburgów wyrosły trzy pokolenia Austriaków. Ale przecież I Republika Austrii była państwem wbrew swej woli, społeczeństwem, które czuło się częścią wielkiego narodu niemieckiego i chciało się przyłączyć do Rzeszy Niemieckiej. Nieprzypadkowo tym, który tego w 1938 r. dokonał, był Austriak, pod całkiem innymi, jak wiemy, politycznymi auspicjami i z fatalnymi skutkami.

Czechosłowacja zaś była państwem, które wierzyło w siebie i swoją misję. Pod względem gospodarczym kraj dysponował najlepszą częścią masy spadkowej dawnej monarchii i był - podobnie jak dzisiaj Republika Czeska - wiodącym państwem przemysłowym, które otwierało się na świat i globalny handel ${ }^{11}$. W administracji państwowej i polityce także znajdujemy głębokie nawiązania do Austro-Węgier. Robert Luft z Collegium Carolinum w Monachium udowodnił to na przykładzie posłów do dawnej Rady Państwa, którzy bardzo często działali dalej jako posłowie nowego parlamentu ${ }^{12}$. Wojsko i służba państwowa także były naznaczone piętnem państwa - poprzednika. Pojęcia tego używam świadomie, ponieważ mówienie jedynie o państwach sukcesyjnych nie dotyka sedna sprawy. Do austriackiej masy spadkowej należały wreszcie pewne defekty strukturalne, jak gdyby działał tu jakiś kod genetyczny. Na pierwszym miejscy stoi niewprowadzony trializm. Jak wskazuje już sama nazwa państwa, Niemcy nie byli przewidziani jako oficjalny naród państwowy, mieli status jedynie mniejszości, choć, jak wiadomo, czysto liczebnie wyprzedzali Słowaków.

Deficyt ten został częściowo wyrównany przez włączenie partii niemieckich do rządu w latach dwudziestych. Tu demokracja okazała więcej zdolności do integracji niż monarchia, na której tego rodzaju ustępstwa

11 Przykładowo ekspansja koncernu obuwniczego Bata poświadczona jest powstaniem licznych fabryk i filii w całym świecie, o czym traktuje tom Tovární města Batova koncernu. Evropská kapitola globální expanze, red. M. Jemelka, O. Ševeček, Praha 2016. O stosunku Czechosłowacji do świata pozaeuropejskiego por. S. Lemmen, Tschechen auf Reisen. Repräsentationen der außereuropäischen Welt und nationale Identität in Ostmitteleuropa 1890-1938, Göttingen 2018.

${ }_{12}$ R. Luft, Parlamentarische Führungsgruppen und politische Strukturen in der tschechischen Gesellschaft. Tschechische Abgeordnete und Parteien des österreichischen Reichsrats 1907-1914, München 2012. Historia partii w dłuższej perspektywie czasowej jest tematem książki Politické strany. Vývoj politických stran a hnutí v českých zemích a Československu 1861-2004, t. 1-2, red. J. Malíř, P. Marek, Brno 2005. 
można było wymóc jedynie po ciężkich kryzysach i klęskach. Demokracja oferowała poza tym bardziej elastyczny podział władzy niż kompromis austriacko-węgierski z 1867 r. czy też późniejsze ugody: morawska (1905), bukowińska (1910) czy galicyjska (1913) ${ }^{13}$. Różnorodne grupy społeczne i partie uczestniczyły w demokracji i rządzie. Partie mogły być zmienione w drodze wyborów, co kiedyś, przy sztywnym podziale władzy wynikającym z ugód, nie było takie łatwe. Prezydentowi Masarykowi udało się w ten sposób częściowo pojednać mniejszość niemiecką z nowym państwem i pozyskać jej lojalność. Jak pokazują nowsze badania, partycypacja polityczna względnie demokracja na ogólnopaństwowym i przede wszystkim na lokalnym poziomie funkcjonowała dobrze ${ }^{14}$.

Współpraca ta jednak kwitła tak długo, jak długo starczało koniunktury gospodarczej. Wskutek światowego kryzysu ekonomicznego w latach trzydziestych kooperacja stała się konfrontacją. Zatem Czechosłowacja była państwem stworzonym na dobre czasy, a nie na złe. Błąd konstrukcyjny czechosłowackiej demokracji polegał na tym, że, pomijając komunistów, nie powstawały ponadnarodowe partie polityczne. Narodowa segmentacja systemu partyjnego i całej demokracji należała wszak do obciążeń dziedzicznych po monarchii.

Również stosunki czesko-słowackie nie rozwijały się wcale tak bratersko jak tego w 1918 r. oczekiwano. Założenie Republiki Czechosłowackiej oznaczało dla ludności słowackiej wyzwolenie zwłaszcza pod względem społecznym. Budowa struktur państwa we wschodnich częściach republiki okazała się jednak trudnym zadaniem. Potrzeba do tego było doświadczonych urzędników administracji, a ci pochodzili przede wszystkim z Czech. Nawet odzyskany z rąk Węgrów teatr w Bratysławie był początkowo zdominowany przez język czeski, ponieważ aktorów i śpiewaków słowackich było za mało. To asymetryczne nation building (termin angielski pasuje tu lepiej niż „tworzenie narodu”) budziło coraz więcej oporu i niechęci. Częściowo było to skutkiem powszechnych w ówczesnej Europie tendencji, jak narastający radykalny nacjonalizm, częściowo mechanizmów społecznych. Przez to, że tak wielu czeskich urzędników, kolejarzy, pocztowców i niektórych przedsiębiorców przeniosło się po

13 O ugodach tych por. G. Stourzh, op. cit., s. 213-229.

${ }^{14}$ Zależy to oczywiście od lokalnego kontekstu. Podczas gdy starsze opracowania, jak np. Jeremy'ego Kinga o Czeskich Budziejowicach, podkreślają raczej konfliktowość relacji, jedna z prac doktorskich powstałych pod mym kierunkiem na Uniwersytecie Wiedeńskim skupia się przede wszystkim na kooperacji i kompromisach ponad etnicznymi granicami. Por. J. Kontny, „Grenzstädte zwischen nationalstaatlicher Ordnung und lokaler Selbstverwaltung. Eupen und Znojmo/Znaim in der Zwischenkriegszeit”, rozprawa doktorska, Historisch-Kulturwissenschaftliche Fakultät, Uniwersytet Wiedeński, 2017. 
1918 r. na Słowację, ich stanowiska były dla Słowaków zajęte. Młodsze pokolenie miało więc ograniczone możliwości społecznego awansu i buntowało się przeciwko asymetrii władzy. Da się to obserwować szczególnie na polu kultury. Jak gdyby powtarzała się historia zakładania czeskiego Teatru Narodowego w Pradze w latach sześćdziesiątych XIX w.: słowaccy pisarze, reżyserzy i aktorzy obstawali przy wydzieleniu własnego teatru narodowego, który został stworzony dopiero na początku lat trzydziestych po stosownych naciskach ${ }^{15}$. To jednak także pokazuje, że Czechosłowacja jako pluralistyczne państwo narodowe była zdolna do rozwoju, bardziej nawet niż Polska, która nie była w stanie iść na analogiczne ustępstwa wobec mniejszości ukraińskiej i od czasów rządu Władysława Grabskiego już nie szukała z nią ugody.

W nowszej literaturze często się to podważa i wskazuje, że demokracja czechosłowacka była nazbyt stabilna, tkwiła niemal w martwym punkcie i istotne decyzje podejmował w zaciszu gabinetów Komitet Pięciu (tak zwana Pětka). Dobrze, że czescy historycy spoglądają krytycznie na własną historię i mit demokratyczny I Republiki ${ }^{16}$. Jednakże, jak poświadczają nowsze studia, także te powstałe pod moją opieką na Uniwersytecie Wiedeńskim, demokracja ta na poziomie lokalnym była nadzwyczaj żywotna i funkcjonowała lepiej niż w niektórych państwach zachodnioeuropejskich, jak na przykład Belgii. W różnych miastach czeskich i szczególnie morawskich w latach dwudziestych i trzydziestych zawarto wiele koalicji politycznych ponad granicami etnicznymi i narodowymi. Tomáš Masaryk cieszył się uznaniem nie tylko wśród Czechów, lecz także licznych Niemców i Słowaków. Przyczyną był jego status, który można nieco ironicznie i całkiem trafnie oddać słowem „cesarz zastępczy" (Ersatzkaiser). Na terenach wschodnich, na Ukrainie Zakarpackiej, do dziś jest on czczony. Tłumaczy się to niekoniecznie tym, kim był, ile raczej gorszymi czasami, które nastały tam po tym, jak Czechosłowacja upadła. Bardzo biedna Ukraina Zakarpacka była w pewnej mierze

15 Po naciskach w 1932 r. został stworzony czysto słowacki zespół. O tym pisze Iris Engemann, Die Slowakisierung Bratislavas. Universität, Theater und Kultusgemeinden 19181948, Wiesbaden 2012, s. 155-165.

${ }^{16}$ Por. O. Konrád, Widersprüchlich und unvollendet. Die Demokratie der Ersten Tschechoslowakischen Republik 1918 bis 1938, „Vierteljahrshefte für Zeitgeschichte” 66, 2018, 2, s. 337-348. Por. poza tym przegląd literatury, opublikowany dwa lata temu w czasopiśmie „Bohemia”: I. Koeltzsch, O. Konrád, From „Islands of Democracy” to „Transnational Border Spaces". State of the Art and Perspectives of the Historiography on the First Czechoslovak Republic since 1989, „Bohemia” 56, 2016, s. 285-327. Zob. tamże interesującą pod względem terminologicznym rozprawę P.J. Howe; T.A. Lorman, D.E. Miller, The Creation of the Conditions for Consociational Democracy and Its Development in Interwar Czechoslovakia, „Bohemia” 56 , 2016, s. 362-380. 
w podobnej pozycji jak Wołyń albo Polesie w Polsce, dostarczała głównie surowców, stanowiąc obszar wewnętrznej kolonizacji ${ }^{17}$. I temu odległemu regionowi dość dobrze udała się integracja z całością organizmu państwowego, w każdym razie w porównaniu z polskimi kresami, gdzie w latach trzydziestych zamachy terrorystyczne ukraińskiego podziemia wstrząsały państwem.

Zwracałem już uwagę na rok 1938, ponieważ jestem przekonany, że dopiero wtedy rzeczywiście zostało usunięte dziedzictwo Austro-Węgier. Oznacza to w konsekwencji, że termin „okres międzywojenny” należałoby przemyśleć, przynajmniej jako rozrywkę dla umysłu. Podobnie jako studia o monarchii naddunajskiej, naznaczony jest on myślą o końcu. Niemal nikt nie wyobrażał sobie, jakie załamanie cywilizacyjne nastąpi po układzie monachijskim (który został wykorzystany przez Polskę do realizacji „interesu narodowego”). Odpowiedzialność za to ponoszą przede wszystkim wielkie mocarstwa - sygnatariusze układu i oczywiście naziści. W 1938 r. objawiła się także pewna wada demokracji. W wyborach samorządowych tego roku partia Niemców sudeckich (SdP) otrzymała 90 proc. głosów, choć jej antydemokratyczne nastawienie było oczywiste i wiedziano, że władza narodowych socjalistów w Niemczech jest dyktatorska i opiera się na masowych represjach oraz obozach koncentracyjnych ${ }^{18}$. Jeśli przywołać maksymę, że wszystkie istotne przełomy historii europejskiej można - jak pod lupą - obserwować na ziemiach czeskich, to demontaż demokracji na drodze wyborów jest cezurą, która mimo wszystkich już istniejących opracowań nadal wymaga bliższego zbadania, i mimo dystansu 80 lat wciąż jesteśmy wobec tego bezradni. Tym bardziej więc wiele przemawia za tym, by obchodząc jubileusze $\mathrm{z}$ ósemką $\mathrm{w}$ dacie nie spychać na drugi plan fatalnego roku 1938 i jego przyczyn.

Spoglądając wstecz, nie powinno się zatem wybielać wewnętrznych konfliktów w Czechosłowacji i w Austro-Węgrzech, nie należy też przeoczyć, że dezintegracja tego wielonarodowego państwa w późnych latach trzydziestych była $\mathrm{w}$ znacznej mierze spowodowana przez podmioty zewnętrzne. Można by było ten osąd odnieść i do, toutes proportions gardées, monarchii habsburskiej, ale należy zauważyć jedną różnicę: Habsburgowie i tak często wychwalany cesarz Franciszek Józef I w 1914 r.

17 O tym zob. S. Holubec, „We bring order, discipline, Western European democracy, and culture to this Land of former oriental chaos and disorder". Czech Perceptions of Sub-Carpathian Rus and its Modernisation in the 1920s, w: Mastery and Lost Illusions. Space and Time in the Modernization of Eastern and Central Europe, red. J. von Puttkamer, W. Borodziej, S. Holubec, München 2014, s. 223-250.

18 Por. D. Brandes, Die Sudetendeutschen im Krisenjahr 1938, München 1980, s. 183 (interpretacja wyników wyborów por. s. 182-193). 
wypowiedzieli wojnę innym państwom ${ }^{19}$, Czechosłowacja nie uczyniła tego nigdy lub - jak kto woli - uczynił to dopiero w $1941 \mathrm{r}$. jej rząd emigracyjny.

To, jak dalece demokracje muszą być zdolne do obrony wewnątrz i na zewnątrz, aby zapewnić sobie na trwałe egzystencję, jest zapewne bardziej aktualną sprawą niż się to komuś podoba. Ale to byłby już temat kolejnego artykułu.

\section{Z jęz. niemieckiego przełożył Bartosz Kaliski}

Biogram: Philipp Ther, profesor Uniwersytetu Wiedeńskiego, dyrektor tamtejszego Instytutu Historii Europy Wschodniej (Institut für Osteuropäische Geschichte). Obszar zainteresowań: społeczna i kulturowa historia Europy Wschodniej w XIX i XX w. (porównawcze studia nad nacjonalizmami, czystki etniczne, muzyka, historia transformacji pokomunistycznej Europy Wschodniej, teoria historii). Dwie jego książki ukazały się jęz. polskim: Ciemna strona państw narodowych. Czystki etniczne w nowoczesnej Europie, Poznań 2012; Nowy ład na Starym Kontynencie. Historia neoliberalnej Europy, Warszawa 2015; kontakt: philipp.ther@univie.ac.at.

${ }^{19}$ Według Judsona łączyły się z tym dalekosiężne cele konserwatywnego i antydemokratycznego przełomu. Por. P. Judson, op. cit., s. 384. Długi czas po II wojnie światowej dominowała teza o austriackiej winie za wojnę i była przekazywana poprzez książki A.J.P. Taylora wielu generacjom studentów w USA i Wielkiej Brytanii. Por. A.J.P. Taylor, The Habsburg Monarchy 1809-1918, 4. wyd., Harmondsworth 1990, s. 230-250. 